(C) 2013

Кравченко С. О., кандидат ветеринарних наук

Полтавська державна аграрна академія

\title{
ВИКОРИСТАННЯ «ЛОРАКСОНУ» ДЛЯ ЛІКУВАННЯ СОБАК ЗА ПНЕВМОНІЙ
}

\section{Рецензент - кандидат ветеринарних наук Н. І. Дмитренко}

Дослідженнями встановлено, щзо застосування антибактеріального препарату «Лораксон» для лікування пневмоній у собак супроводжується нормалізацією клінічного стану хворих тварин та окремих морфологічних $і$ біохімічних показників крові. Після введення препарату «Лораксон» внутрішньом'язево, в дозі 30 мг/кг, двічі на добу впродовж 7 діб у хворих собак покрашується загальний стан, відновлюється апетит та зникає лихоманка на другу добу. Кількість лейкоцитів зменшується до меж показників клінічно здорових тварин, нормалізуються показники білкового обміну, а саме вмісту загального білку та частки глобулінів, на сьому добу.

Ключові слова: «Лораксон», собаки, пневмонія, лікування, кров, біохімічні показники.

Постановка проблеми. Захворювання легень запального характеру у собак складають значну частину внутрішньої незаразної патології тварин даного виду $[1,2,8]$. Ця проблема завдає суттєвих збитків передусім службовому та мисливському собаківництву, оскільки собаки нерідко зазнають впливу патогенних чинників, таких як переохолодження, тривалі фізичні навантаження, стрес, поранення, що сприяє зниженню природної резистентності та спричиняє запалення легень.

Як свідчать літературні джерела, саме пневмонія постає найпоширенішою патологією системи органів дихання, що призводить до захворювання та загибелі собак $[5,7]$.

Пневмонія в собак дуже часто перебігає субклінічно, тому на момент встановлення діагнозу запальний процес охоплює значну частину легень. Тому хворі тварини потребують інтенсивної терапії, із призначенням антибактеріальних препаратів та засобів патогенетичної терапії.

Виходячи 3 вищевказаного, вивчення ефективності антибіотиків для лікування пневмоній у собак залишається актуальним.

Аналіз основних досліджень і публікацій, у яких започатковано розв'язання проблеми. Проблема вибору антибактеріальних засобів у стратегії лікування внутрішніх хвороб тварин завжди залишається нагальною для фахівців ветеринарної медицини. Питанню обгрунтованого призначення антибіотиків присвячено значну кі- лькість публікацій - як у складі відповідних розділів навчально-методичної літератури $[1,2]$, так і наукових праць [9].

Узагальнюючи літературні дані, слід сказати, що максимально грунтовним призначення протимікробних препаратів можна вважати лише після встановлення чутливості патогенної мікрофлори, виділеної з осередку запалення.

Проте такі дослідження потребують певного часу, що становить не менше 72 годин. Але стан хворої тварини (а надто за гострого перебігу пневмоніï) не дозволяє залишити іiі без етіотропної терапії такий тривалий час.

Тому лікар ветеринарної медицини часто знаходиться у ситуації, коли призначити антибіотик необхідно негайно, керуючись настановою до використання препарату та виходячи з переліку доступних та ефективних засобів $[1,5,9]$.

Окрім того, як показує практика, стійкість мікрофлори до більшості антибіотиків становить чи не найбільшу складність у лікуванні тварин, хворих на пневмонію, особливо змішаної етіологіï.

Тому пошук та апробація ефективних антибактеріальних засобів у лікуванні собак, хворих на пневмонію, є вкрай необхідними.

Мета і завдання дослідження. Мета дослідження - вивчення ефективності застосування препарату «Лораксон» для лікування пневмоній у собак.

Основним завданням було лікування хворих на пневмонію собак, аналіз змін клінічного стану та лабораторних показників крові.

Матеріали і методи. Дослідження проводили в умовах клініки ветеринарної медицини на базі кафедри терапії ПДАА у період із 2011 по 2013 роки.

Собак, які надходили з ознаками патології системи органів дихання, обстежували клінічно та проводили лабораторні дослідження крові.

Відбирали кров із поверхневої вени передпліччя.

Визначали кількість лейкоцитів мікроскопією у камері із сіткою Горяєва та виводили лейкоформулу за Філіпченком [3].

У сироватці крові визначали вміст загального 


\section{ВЕТЕРИНАРНА МЕДИЦИНА}

білку, альбумінів та глобулінів за допомогою універсального біохімічного аналізатора.

Хворих тварин лікували, застосовуючи препарат «Лораксон» - антибіотик цефалоспоринового ряду третього покоління (діюча речовина - цефтриаксон), бактерицидна дія якого відбувається за рахунок руйнування клітинної мембрани мікроорганізмів. Він має широкий спектр бактерицидної дії на грам-позитивні та грам-негативні мікроорганізми [6].

«Лораксон» призначали внутрішньом'язево, у дозі 30 мг/кг маси тіла, за два введення 3 інтервалом 12 годин упродовж 7 днів.

У якості вітамінотерапії застосовували комплексний препарат «Інтровіт» підшкірно у дозі 1-5 мл, кожну третю добу, три ін'єкції.

Для підвищення природної резистентності організму застосовували настоянку ехінацеї пурпурової внутрішньо, по 6-10 крапель щодоби, впродовж 7 днів [4].

Матеріалом для досліджень стали клінічно здорові та хворі на пневмонію собаки.

У ході виконання роботи використано результати досліджень 10 клінічно здорових та 6 хворих на пневмонію собак.

Усі тварини, які надходили до клініки, підлягали клінічному обстеженню. За наявності клінічних ознак пневмонії у собак відбирали кров та застосовували лабораторні дослідження, які повторювали на сьомий день лікування.

Результати досліджень. У ході досліджень було встановлено, що клінічними ознаками пневмонії у собак були: тахіпное, сухий і болючий кашель, гіпорексія, лихоманка (до 40,6 ${ }^{0} \mathrm{C}$ ), тахікардія, притуплений звук при перкусії легень, при аускультації - патологічне бронхіальне дихання та локальні сухі хрипи.

Лабораторними дослідженнями було встановлено, що морфологічні та біохімічні показники крові хворих собак відрізняються від таких у клінічно здорових тварин (див. табл.).

Так, спостерігали лейкоцитоз (на 66,0%), переважно внаслідок збільшення відносної кількості паличкоядерних форм нейтрофілів (у 2,7 ра3у).

Ці клітини беруть участь у захисті організму від токсичного впливу патогенних мікроорганізмів шляхом фагоцитозу та транспортують антитіла до осередку інфекції.

При цьому зрілі нейтрофіли (сегментоядерні) гинуть, що призводить до вивільнення депонованих у кістковому мозку більш молодих форм.

Відмічали також лімфоцитопенію, що характерно для запалення легень.
Зменшення кількості лімфоцитів у кров'яному руслі пояснюється міграцією цих лейкоцитів у осередок запалення, оскільки їх захисна дія полягає у формуванні клітинної і гуморальної імунної відповіді.

Вміст загального білку сироватки крові собак за пневмонії виявився меншим за показники клінічно здорових тварин на $16,2 \% \quad(58,4 \pm 4,91$ проти $69,7 \pm 3,82$ г/л), переважно за рахунок фракції альбумінів (їх частка менша на $12,4 \%$ ), тоді як вміст глобулінів у хворих тварин більший на $18,7 \%$.

Такі зміни протеїнограми свідчать про розвиток кисневого голодування та інтоксикації і водночас про перебіг гострого запального процесу, які супроводжують гострий перебіг пневмонії.

Отже, отримані результати досліджень крові, у поєднанні із клінічними ознаками, дозволили комплексно діагностувати пневмонію у хворих тварин.

У ході лікування спостереження клінічного стану тварин проводили щоденно.

Спостерігали позитивну динаміку.

Так, після другої ін'єкції препарату «Лораксон» температура тіла у собак зменшилася до норми і лише у двох тварин становила 39,2$39,4{ }^{\circ}$ C. Кашель ставав вологим та нечастим, відновлювався апетит. На 4-5-й день вже не реєстрували тахікардії і тахіпное.

Звук при перкусії легень залишався притупленим до шостого дня, а поодинокі хрипи у трьох тварин відмічали і на сьомий день спостереження.

Загальний клінічний стан тварин можна визначити як задовільний.

Результати дослідження крові собак після лікування показали, що кількість лейкоцитів зменшилась у середньому до $11,4 \pm 1,52$ Г/л, част-

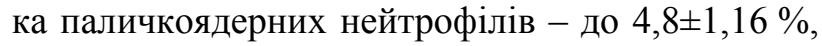
а частка лімфоцитів зросла до 29,9\%, тобто отримані показники наближаються до результатів клінічно здорових тварин.

Також збільшився вміст загального білку сироватки крові в середньому до $65,7 \pm 2,94$ г/л, що вірогідно не відрізняється від показника клінічно здорових, а кількість глобулінів зменшилася на 10,3 \% (порівняно 3 показником до лікування), що свідчить про поступове відновлення білкового складу крові хворих собак.

Таким чином, у тварин у процесі лікування за обраною схемою спостерігали покращання показників клінічного стану та відновлення показників лейкопоезу і білкового складу крові. 
ВЕТЕРИНАРНА МЕДИЦИНА

Вміст лейкоцитів та лейкограма крові собак, хворих на пневмонію

\begin{tabular}{|c|c|c|c|c|c|c|c|}
\hline \multirow{2}{*}{\multicolumn{3}{|c|}{ Показник }} & \multicolumn{2}{|c|}{$\begin{array}{c}\text { Клінічно здорові } \\
\text { тварини }(\Pi=10)\end{array}$} & \multicolumn{2}{|c|}{$\begin{array}{c}\text { Хворі тварини } \\
(\mathrm{n}=6)\end{array}$} & \multirow{2}{*}{$\mathrm{p}<$} \\
\hline & & & Lim & $\mathrm{M} \pm \mathrm{m}$ & Lim & $\mathrm{M} \pm \mathrm{m}$ & \\
\hline \multicolumn{3}{|c|}{ Лейкоцити, Г/л } & $8,3-11,2$ & $9,4 \pm 0,61$ & $12,5-17,8$ & $15,6 \pm 1,82$ & 0,001 \\
\hline \multirow{7}{*}{ 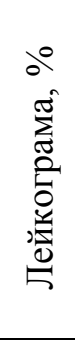 } & \multirow{2}{*}{\multicolumn{2}{|c|}{ еозинофіли }} & $0-1,0$ & $0,5 \pm 0,21$ & $0-1,0$ & $0,5 \pm 0,16$ & - \\
\hline & & & $2,0-4,0$ & $3,6 \pm 0,31$ & $2,0-6,0$ & $4,7 \pm 0,61$ & 0,5 \\
\hline & \multirow{3}{*}{ 总 } & юні & $0,0-1,0$ & $0,5 \pm 0,23$ & $0,0-1,0$ & $0,6 \pm 0,29$ & 0,5 \\
\hline & & паличкоядерні & $2,0-5,0$ & $3,5 \pm 0,82$ & $8,0-12,0$ & $9,6 \pm 1,25$ & 0,001 \\
\hline & & сегментоядерні & $42,0-64,0$ & $55,8 \pm 2,38$ & $52,0-71,0$ & $57,4 \pm 1,03$ & 0,5 \\
\hline & \multicolumn{2}{|c|}{ лімфоцити } & $29,0-37,0$ & $33,6 \pm 1,4$ & $19,0-26,0$ & $24,0 \pm 2,9$ & 0,05 \\
\hline & \multicolumn{2}{|c|}{ моноцити } & $2,0-4,0$ & $2,5 \pm 0,62$ & $3,0-5,0$ & $3,2 \pm 0,35$ & 0,5 \\
\hline
\end{tabular}

Висновок. Застосування препарату «Лораксон» для лікування собак, хворих на пневмонію, $\epsilon$ ефективним, що підтверджується комплексом

\section{БІБЛІОГРАФІЯ}

1. Болезни собак и кошек. Комплексная диагностика и терапия болезней собак и кошек : учеб. пособие / [Т. К. Донская Г. Г. Щербаков, Г. В. Полушин] ; под ред. С. В. Старченкова. СПб. : Спец. литература, 2006. - 655 с.

2. Внутрішні хвороби тварин / В.І. Левченко, І. П. Кондрахін, В.В. Влізло [та ін.] ; за ред. В. І. Левченка. - Біла Церква, 2012. - Ч. 1. - 528 с.

3. Клиническая лабораторная диагностика в ветеринарии: Справочное издание / [И. П. Кондрахин, Н. В. Курилов, А. Г. Малахов и др.].М. : Агропромиздат, 1985. - 287 с.

4. Локес П. І. Лікарські рослини : Підручник / П. І. Локес, І. Г. Панасенко. - Полтава : Довкілля, 2010. -264 c.

5. Ниманд Х. Г. Болезни собак / Х. Г. Ниманд, П. Б. Сутер ; пер. с англ. - М. : Аквариум ЛТД, змін клінічних ознак та лабораторних показників крові хворих тварин у динаміці.

2001. - C. 604-608.

6. Пламб Д. К. Фармакологические препараты в ветеринарной медицине / Д. К. Пламб ; пер. с англ. Е. И. Осипова. - М. : Аквариум ЛТД, 2002. $-856 \mathrm{c}$.

7. Фасоля В. П. Вікова, нозологічна і породна структура хвороб собак у м. Житомирі / В. П. Фасоля // Вісник Білоцерків. держ. аграр. ун-ту - Біла Церква, 2001. - Вип. 28. - С. 256258.

8. Хвороби собак і кішок / В. Б. Борисевич, В. Ф. Галат, Г. М. Калиновський [та ін.] ; за ред. А. Й. Мазуркевича. - К. : Урожай, 1996. - 432 с.

9. Kaneko J. J. Clinical biochemistry of domestic animals / J. J. Kaneko, I. W. Harvey, M. L. Bruss. New York : Academmic Press, 1997. - 932 p. 